Article

\title{
No Effect Level of Co-Composted Biochar on Plant Growth and Soil Properties in a Greenhouse Experiment
}

\author{
Hardy Schulz ${ }^{1, *}$, Gerald Dunst ${ }^{2}$ and Bruno Glaser ${ }^{1}$
}

1 Soil Biogeochemistry, Martin-Luther-University Halle-Wittenberg, Von-Seckendorff-Platz 3, Halle 06120, Germany; E-Mail: bruno.glaser@landw.uni-halle.de

2 Sonnenerde, Oberwarterstraße 100, Riedlingsdorf A-7422, Austria; E-Mail: g.dunst@sonnenerde.at

* Author to whom correspondence should be addressed; E-Mail: hardy.schulz@gmail.com;

Tel.: +49-176-620-898-32.

Received: 10 October 2013; in revised form: 13 December 2013 / Accepted: 23 December 2013 /

Published: 22 January 2014

\begin{abstract}
It is claimed that the addition of biochar to soil improves $\mathrm{C}$ sequestration, soil fertility and plant growth, especially when combined with organic fertilizers such as compost. However, little is known about agricultural effects of small amounts of composted biochar. This greenhouse study was carried out to examine effects of co-composted biochar on oat (Avena sativa L.) yield in both sandy and loamy soil. The aim of this study was to test whether biochar effects can be observed at very low biochar concentrations. To test a variety of application amounts below $3 \mathrm{Mg}$ biochar ha ${ }^{-1}$, we co-composted five different biochar concentrations $\left(0,3,5,10 \mathrm{~kg} \mathrm{Mg}^{-1}\right.$ compost). The biochar-containing compost was applied at five application rates $(10,50,100,150$, $250 \mathrm{Mg} \mathrm{ha}^{-1} 20 \mathrm{~cm}^{-1}$ ). Effects of compost addition on plant growth, Total Organic Carbon, $\mathrm{N}_{\text {tot }}, \mathrm{pH}$ and soluble nutrients outweighed the effects of the minimal biochar amounts in the composted substrates so that a no effect level of biochar of at least $3 \mathrm{Mg} \mathrm{ha}^{-1}$ could be estimated.
\end{abstract}

Keywords: biochar; compost; no-effect-level; greenhouse; C management

\section{Introduction}

Many studies on biochar effects in different soil substrates have been scientifically examined during the last decade, the majority thereof proving positive effects on plant growth and soil properties [1-3]. 
In a recent meta-analysis study, Jeffery et al. [4] reviewed 177 treatments from 16 individual studies and found only one with negative impacts on plant growth but several studies showing no biochar effect on plant growth.

Usually biochars are low in nutrients, depending on feedstock and pyrolysis temperature $[5,6]$. This limited supply of nutrients implies additional fertilization if biochar is applied for agricultural purposes. Recent studies suggested adding biochar to compost [7] or even better co-composting biochar [8,9] as a preferable alternative to input intensive or finite (phosphorus) fertilizer. Another study claims that biochar increases the nutrient retention of the existing nutrients in compost due to the increase of biochar surface oxidation when biochar is applied into the fresh compost mixture. In other words: abiotic and biotic processes during composting lead to the formation of oxygen-containing functional groups and therewith to an increase of nutrient holding capacity [10].

Research already opposed maximum biochar application amounts, as shown by Schulz and Glaser [9] who applied biochar amounts of up to $90 \mathrm{Mg} \mathrm{ha}^{-1}$ in the form of co-composted biochars, which induced increased plant growth, and the more biochar added to the soil, the more carbon storage potential there was. However, from a farmer's perspective minimal biochar amounts are desirable due to economic reasons. The economic cost of biochar is in a range of \$200-\$2,000 per Mg (worldwide, data from online market research). In addition, companies being able to supply more than $1 \mathrm{Mg}$ per day are still rare in Europe [11].

Due to our knowledge, little is known on threshold amounts of biochar for positive agronomic effects. Only one other study is published with similarly small biochar application amounts, still this is not comparable to our setup as they calculated per hectare amounts but applied the biochar in relatively small bands only surrounding the sown seeds (approximately one $\mathrm{Mg} \mathrm{ha}^{-1}[12]$ ).

Our study was designed by combining the knowledge of synergistic effects that composting has on biochar with the need to find no effect level (NOEL) for biochar amendments. Therefore, we investigated the effects of both (i) biochar addition rate and (ii) co-composted biochar application amount on oat (Avena sativa L.) yield. We hypothesized that (1) co-composted biochar amended soil increases the TOC (with positive effects on soil water status); (2) retains more nutrients in the available form and (3) results in higher crop yields.

\section{Materials and Methods}

\subsection{Soil Substrates}

For our study we used a sandy and a loamy substrate which had not been used for agricultural purposes prior to the experiment. The substrates were collected at Kiesgrube ZAPF, Weidenberg, Germany and Ökologisch Botanischer Garten, University of Bayreuth, Germany, respectively. Selected basic properties of soil substrates are given in Table 1. The very poor sandy substrate (which was washed sand-mix originally intended for concrete mixes) was representative of nutrient-poor infertile soil, while the loamy substrate represented soils with sufficient nutrient supply common in Central Europe. Strongly contrasting contents of organic material and clay size particles of the two substrates were supposed to induce different responses comparable to natural soil types. 
Table 1. Chemical composition of the two soil substrates and the biochar composts are shown. "CO" is compost without biochar. The number following "BC-" denotes the approximate fraction of biochar in the composted product as "kg biochar per Mg". "n.a." means not analyzed. "BET" is BET surface area, " $\pm \mathrm{se}$ " means plus minus standard error $(n=5)$.

\begin{tabular}{|c|c|c|c|c|c|c|c|c|c|c|c|c|c|c|}
\hline & $\begin{array}{c}\text { Al } \\
{\left[\mathrm{g} \mathrm{kg}^{-1}\right]}\end{array}$ & $\begin{array}{c}\text { Ca } \\
{\left[\mathrm{g} \mathrm{kg}^{-1}\right]}\end{array}$ & $\begin{array}{c}\mathbf{K} \\
{\left[\mathrm{g} \mathrm{kg}^{-1}\right]}\end{array}$ & $\begin{array}{c}\text { Mg } \\
{\left[\mathrm{g} \mathrm{kg}^{-1}\right]}\end{array}$ & $\begin{array}{c}\mathbf{N a} \\
{\left[\mathrm{g} \mathrm{kg}^{-1}\right]}\end{array}$ & $\begin{array}{c}\mathbf{P} \\
{\left[\mathrm{g} \mathrm{kg}^{-1}\right]}\end{array}$ & $\begin{array}{c}\text { Biochar } \\
{\left[\mathrm{g} \mathrm{kg}^{-1}\right]}\end{array}$ & $\begin{array}{c}\text { TOC } \\
{\left[\mathrm{g} \mathrm{kg}^{-1}\right]}\end{array}$ & $\begin{array}{c}\mathbf{N} \\
{\left[\mathrm{g} \mathrm{kg}^{-1}\right]}\end{array}$ & $\mathbf{C} / \mathbf{N}$ & Ash & $\begin{array}{c}\text { NO3 } \\
{\left[\mathrm{g} \mathrm{kg}^{-1}\right]}\end{array}$ & $\begin{array}{c}\text { NH4 } \\
{\left[\mathrm{g} \mathrm{kg}^{-1}\right]}\end{array}$ & $\begin{array}{c}\mathbf{B E T} \pm \mathbf{s e} \\
{\left[\mathrm{m}^{2} \mathrm{~g}^{-1}\right]}\end{array}$ \\
\hline Sand & 0.068 & 0.118 & 0.008 & 0.025 & 0.007 & 0.008 & 0 & 0.96 & n.a. & n.a. & n.a. & n.a. & n.a. & n.a. \\
\hline Loam & 0.683 & 2.511 & 0.202 & 0.333 & 0.030 & 0.091 & 0 & 16.09 & n.a. & n.a. & n.a. & n.a. & n.a. & n.a. \\
\hline $\mathrm{CO}$ & 11.0 & 3390 & 302 & 103 & 45.4 & 24.7 & 0 & 112.83 & 9.46 & 13.41 & 78.40 & 0.25 & 0.06 & $2.3 \pm 0.3$ \\
\hline BC-03 & 7.9 & 3610 & 312 & 103 & 46.7 & 22.0 & 3 & 120.52 & 9.85 & 13.63 & 77.80 & 0.32 & 0.04 & $11.6 \pm 0.8$ \\
\hline BC- 05 & 8.0 & 3510 & 292 & 100 & 44.4 & 25.3 & 5 & 117.36 & 9.69 & 13.48 & 77.40 & 0.34 & 0.03 & $12.7 \pm 0.1$ \\
\hline BC-10 & 7.8 & 3590 & 325 & 107 & 51.0 & 23.9 & 10 & 122.11 & 9.43 & 14.31 & 76.20 & 0.36 & 0.06 & $12.9 \pm 0.7$ \\
\hline
\end{tabular}




\subsection{Biochar Composts}

The biochar was an activated carbon from a commercial producer (carbopal ${ }^{\circledR}$, Donau Carbon $\mathrm{GmbH}$, Frankfurt, HE, Germany, ash content $<6 \%$, bulk density $\sim 0.6 \mathrm{~g} / \mathrm{cm}^{3}$, surface area $\sim 900 \mathrm{~m}^{2} / \mathrm{g}$, specific surface $1200 \mathrm{~m}^{2} / \mathrm{g}$, bulk density $\sim 375 \mathrm{~kg} / \mathrm{m}^{3}$ ). Compost input material consisted of $50 \%$ sewage sludge (25\% dry matter), $35 \%$ chopped wood $(60 \% \mathrm{dm})$ and $15 \%$ rest soil or woody debris (leftovers from composting). After piling $20 \mathrm{Mg}$ compost raw material to six meter wide and three meter high piles for two weeks, the piles were diverted into three meter wide and $1.5 \mathrm{~m}$ high mounds and mixed twice a week. After the biochar was added to respective piles in amounts of 3.5 and $10 \mathrm{~kg}$ biochar per $\mathrm{Mg}$ compost (BC-03, BC-05 and BC-10, respectively) and composted together for two weeks (mixed once a week) before the final phase of composting was induced by piling six meter wide and three meter high mounds (mixed every third week). Properties of individual biochar-amended composts are given in Table 1 .

\subsection{Greenhouse Experiment}

The study was set up in a greenhouse at an average temperature of around $22{ }^{\circ} \mathrm{C}$, with $200 \mathrm{~mL}$ of water irrigation every other day, and constant light conditions ( $400 \mathrm{~W}$ sodium discharge lamp, $8 \mathrm{~h}$ per day) for the whole duration of the experiment. For the experiment, we used commercial plastic pots with a total volume of $1000 \mathrm{~cm}^{3}$ and a diameter of $13 \mathrm{~cm}$, with a surface area of $133 \mathrm{~cm}^{2}$. The perforated bottoms were covered with fine gauze, hindering the loss of particulate matter but allowing leaching of water. One kilogram of dry matter of the substrate was placed in the pots. The biochar compost types were applied in five application rates (equivalent to $10,50,100,150,250 \mathrm{Mg} \mathrm{ha}^{-1}$ $20 \mathrm{~cm}^{-1}$ in five replicates); hence, the respective biochar component application rates were between 0.03 and $2.5 \mathrm{Mg} \mathrm{ha}^{-1}$ (Figure 1). Soil samples were taken at time zero, after mixing and before sowing. All pots were arranged in a randomized block design and 10 oat (Avena sativa L.) seeds were sown in each pot, similar to common oat sowing in the field at 500-700 seeds per square meter. The survival rate was noted at harvest time and plants were cut just above the ground leading to the biomass data. Seeds were separated manually afterwards and weighed separately.

\subsection{Soil and Plant Analyses}

Three months after sowing, the plants' heights were recorded and we harvested above-ground biomass. Plant biomass was dried at $65{ }^{\circ} \mathrm{C}$ and then weighted. Results were scaled up to $\mathrm{Mg} \mathrm{ha}^{-1}$ using the pot surface area. Composted biochars and soil samples were analyzed using the Mehlich-III-extraction method [13]. To do so, $2.5 \mathrm{~g}$ of soil was passed through a $2 \mathrm{~mm}$ sieve into $125 \mathrm{~mL}$ Erlenmeyer flasks, and $30 \mathrm{~mL}$ of Mehlich-III-extractant $\left(0.2 \mathrm{M} \mathrm{CH}_{3} \mathrm{COOH}, 0.25 \mathrm{M} \mathrm{NH}_{4} \mathrm{NO}_{3}\right.$, $0.015 \mathrm{M} \mathrm{NH}_{4} \mathrm{~F}, 0.013 \mathrm{M} \mathrm{HNO}_{3}$ and $0.001 \mathrm{M}$ EDTA.) added. The suspension was shaken for 5 min on a rotating shaker with $120 \mathrm{rpm}$. After filtrating through No. 42 Whatman filter paper, filtrates were analyzed by ICP-OES (BayCEER, University of Bayreuth). Total organic carbon (TOC) and total nitrogen $(\mathrm{N})$ were measured by dry combustion with a VARIOMAX CNS elemental analyzer (Elementar, Hanau, Germany). 
Figure 1. Individual amounts of applied compost and biochar $(\mathrm{CO}=$ pure compost, BC-03 = compost with $3 \mathrm{~kg} \mathrm{Mg}^{-1} w / w$ biochar, BC-05 = compost with $5 \mathrm{~kg} \mathrm{Mg}^{-1} w / w$ biochar, $\mathrm{BC}-10=$ compost with $10 \mathrm{~kg} \mathrm{Mg}^{-1} w / w$ biochar) at 5 application amounts $(10,50$, 100, 150, $250 \mathrm{Mg} \mathrm{ha}^{-1}$ ) calculated as per hectare amounts (in $\mathrm{Mg} \mathrm{ha}^{-1}$ ).
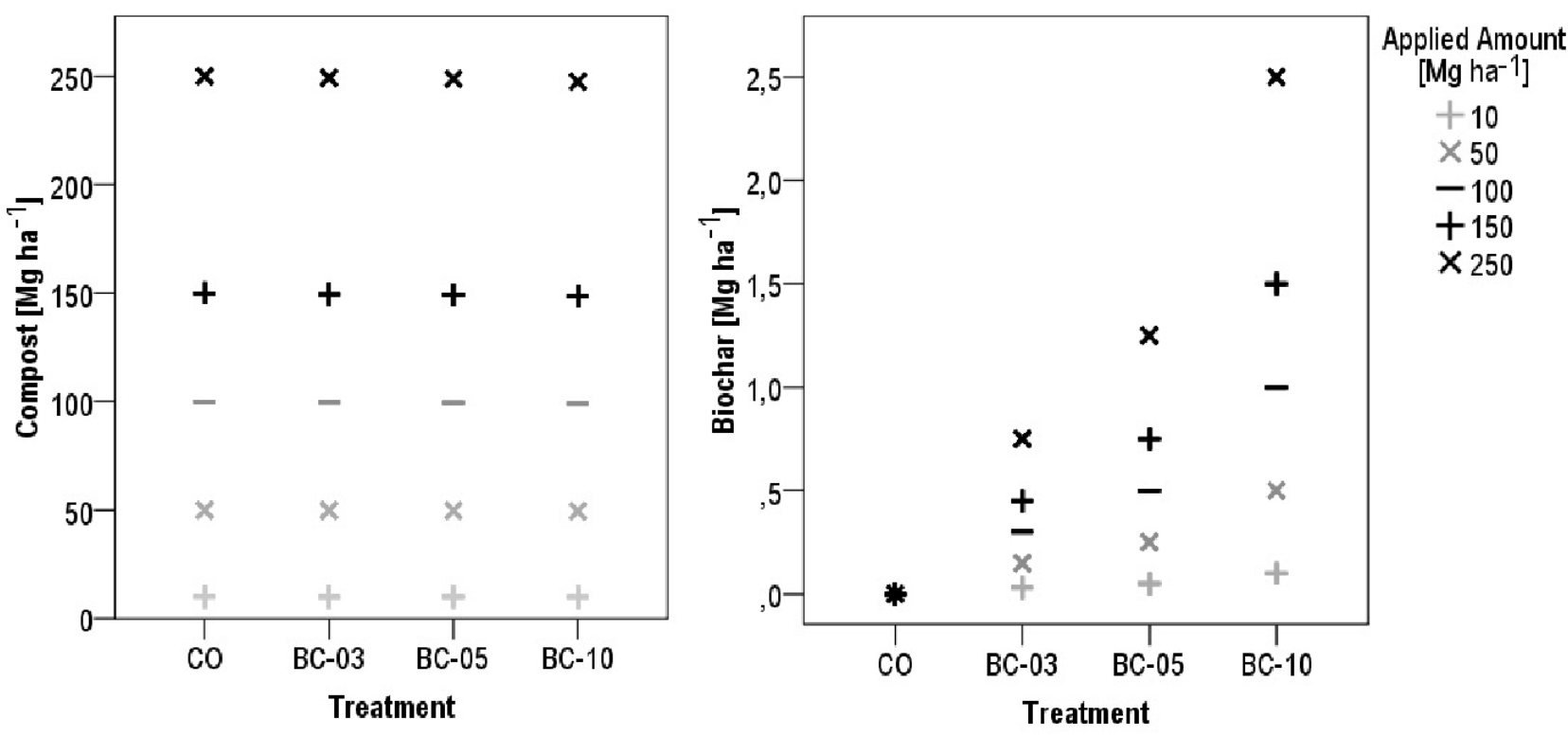

\subsection{Statistical Analysis}

Data were analyzed using simple linear regressions (SLR) with the equivalent per hectare amounts of composted biochars or composts to analyze biochar and compost effects separately; regression coefficients are indicated if significant (justification for this procedure is found in setup description, Figure 1). Asterisks *,**,*** indicate $p<0.05, p<0.01, p<0.001$, respectively; not significant data is indicated by "n.s." in the tables. The values behind " \pm "symbols in the text represent one standard error of the mean $(n=5)$. All analyses were performed with SPSS Statistics 17 (IBM).

\section{Results}

\subsection{Plant Growth}

\subsubsection{Oat Grain Yield}

The oat grain yield ranged between 0.00 and $0.14 \mathrm{Mg} \mathrm{ha}^{-1}$ on sandy substrate (control: $0.02 \pm 0.00 \mathrm{Mg} \mathrm{ha}^{-1}$ ) and between 0.04 and 0.19 on loamy substrate (control: $0.06 \pm 0.00 \mathrm{Mg} \mathrm{ha}^{-1}$; Figure 2). Compost significantly increased grain yield (sandy: $p<0.001$; loamy substrate: $p=0.001$; Table 2), while no effect of biochar on oat yield could be proven ( $p>0.05$ at all applied amounts and on both substrates; Table 2). 
Figure 2. Grain biomass (top) and plant biomass (bottom) of oat (Avena sativa L.) in $\mathrm{Mg} \mathrm{ha}{ }^{-1}$ on sandy (left) and loamy substrate (right) depicted for five treatments $\left(\mathrm{CO}=\right.$ pure compost, $\mathrm{BC}-03=$ compost with $3 \mathrm{~kg} \mathrm{Mg}^{-1} w / w$ biochar, $\mathrm{BC}-05=$ compost with $5 \mathrm{~kg} \mathrm{Mg}^{-1} w / w$ biochar, BC-10 = compost with $10 \mathrm{~kg} \mathrm{Mg}^{-1} w / w$ biochar, in five application amounts $\left(10,50,100,150,250 \mathrm{Mg} \mathrm{ha}^{-1}\right)$ versus control $(\mathrm{CTRL}=$ no amendment) $(n=5)$.

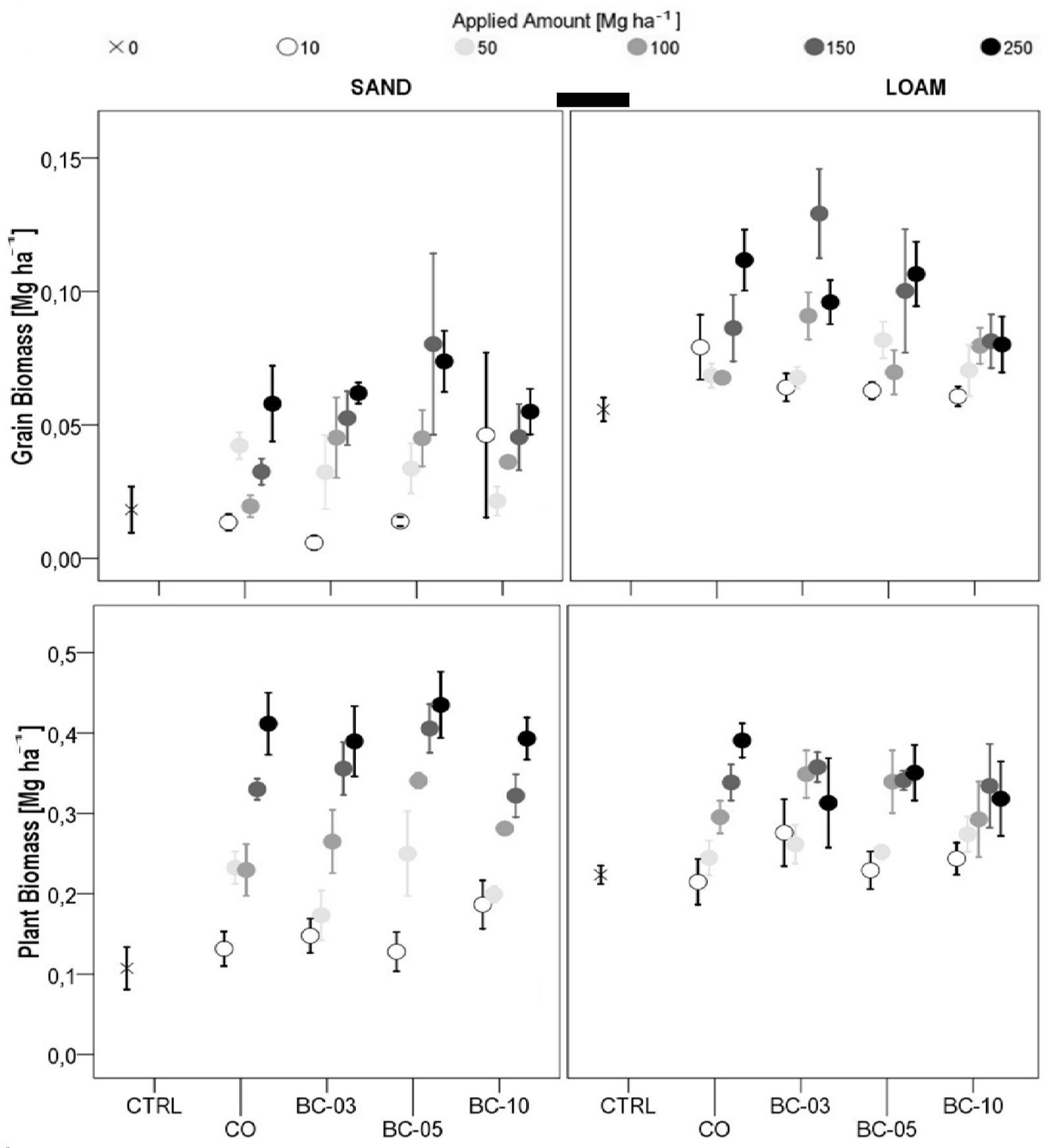


Table 2. Linear regression of plant and soil data calculated with per hectare amounts of the applied biochar composts. "CO" stands for regressions with the compost amounts and the variables, "BC" for the biochar amount and the variables. If "BC" had significant influence on the variables, the respective application amount is indicated by the superscript number.

\begin{tabular}{|c|c|c|c|c|c|}
\hline Substrate & Variable & Regression (CO) & & Regression (BC) & \\
\hline \multirow{12}{*}{ Sand } & Seed yield & $1.85+0.02 \times \mathrm{CO}$ & $* * *$ & n.s & \\
\hline & Biomass & $16.48+0.10 \times \mathrm{CO}$ & $* * *$ & n.s. & \\
\hline & Plant height & $73.00+0.11 \times \mathrm{CO}$ & $* * *$ & $101.31-8.11 \times \mathrm{BC}^{150}$ & * \\
\hline & TOC & $2.71+0.01 \times \mathrm{CO}$ & $* * *$ & $0.97+33.50 \times \mathrm{BC}^{10}$ & $* *$ \\
\hline & $\mathrm{TN}$ & $0.22+0.00 \times \mathrm{CO}$ & $* * *$ & n.s. & \\
\hline & $\mathrm{pH}$ & $8.54+0.00 \times \mathrm{CO}$ & $* * *$ & n.s. & \\
\hline & $\mathrm{P}$ & $0.056+0.001 \times \mathrm{CO}$ & $* * *$ & n.s. & \\
\hline & $\mathrm{K}$ & $0.009+0.000 \times \mathrm{CO}$ & $* * *$ & $\begin{array}{l}0.018-0.130 \times \mathrm{BC}^{10} \\
0.011+0.011 \times \mathrm{BC}^{50} \\
0.030+0.008 \times \mathrm{BC}^{250}\end{array}$ & $\begin{array}{l}* \\
* \\
*\end{array}$ \\
\hline & $\mathrm{Mg}$ & $0.043+0.000 \times \mathrm{CO}$ & $* * *$ & $0.079+0.015 \times \mathrm{BC}^{250}$ & * \\
\hline & $\mathrm{Ca}$ & $0.574+0.008 \times \mathrm{CO}$ & $* * *$ & n.s. & \\
\hline & $\mathrm{Na}$ & $0.011+0.000 \times \mathrm{CO}$ & $* * *$ & n.s. & \\
\hline & $\mathrm{Al}$ & $0.105-0.000 \times \mathrm{CO}$ & n.s. & n.s. & \\
\hline \multirow{12}{*}{ Loam } & Seed yield & $6.66+0.01 \times \mathrm{CO}$ & $* *$ & n.s & \\
\hline & Biomass & $26.18+0.04 \times \mathrm{CO}$ & $* * *$ & $41.04-4.69 \times \mathrm{BC}^{250}$ & $*$ \\
\hline & Plant height & $87.49+0.02 \times \mathrm{CO}$ & n.s. & n.s. & \\
\hline & TOC & $18.99+0.03 \times \mathrm{CO}$ & $* * *$ & $25.19-9.79 \times \mathrm{BC}^{100}$ & $*$ \\
\hline & $\mathrm{TN}$ & $1.66+0.00 \times \mathrm{CO}$ & $* * *$ & n.s. & \\
\hline & $\mathrm{pH}$ & $7.21+0.00 \times \mathrm{CO}$ & $* * *$ & n.s. & \\
\hline & $\mathrm{P}$ & $0.131+0.001 \times \mathrm{CO}$ & $* * *$ & n.s. & \\
\hline & K & $0.193+0.000 \times \mathrm{CO}$ & $* * *$ & $0.240-0.662 \times \mathrm{BC}^{50}$ & $* *$ \\
\hline & $\mathrm{Mg}$ & $0.345+0.000 \times \mathrm{CO}$ & $* * *$ & n.s. & \\
\hline & $\mathrm{Ca}$ & $2.942+0.009 \times \mathrm{CO}$ & $* * *$ & $3.105+0.897 \times \mathrm{BC}^{50}$ & $*$ \\
\hline & $\mathrm{Na}$ & $0.04+0.000 \times \mathrm{CO}$ & $* * *$ & $0.043-0.174 \times \mathrm{BC}^{10}$ & $* *$ \\
\hline & $\mathrm{Al}$ & $0.668-0.000 \times \mathrm{CO}$ & $* * *$ & n.s. & \\
\hline
\end{tabular}

Significant differences are marked with asterisks: ${ }^{*}, * * * *$ indicate $p<0.05, p<0.01, p<0.001$, respectively; n.s. indicates "not significant". Seed yield $=$ separated seeds, Biomass $=$ complete above ground biomass. 


\subsubsection{Plant Biomass}

Total above-ground biomass yield ranged between $0.02-0.54 \mathrm{Mg} \mathrm{ha}^{-1}$ on sandy substrate (control: $0.11 \pm 0.01 \mathrm{Mg} \mathrm{ha}^{-1}$ ) and between $0.10-0.48 \mathrm{Mg} \mathrm{ha}^{-1}$ on loamy substrate (control: $0.22 \pm 0.01 \mathrm{Mg} \mathrm{ha}^{-1}$; Figure 2). Compost application significantly increased oat biomass both on sandy $(p<0.001)$ and loamy substrates (Table 2). Biochar showed no significant effect on plant biomass on sandy substrate, while on loamy substrate biomass yield was significantly lower at the highest applications amounts (250 $\mathrm{Mg} \mathrm{ha}^{-1} ; p=0.04$ ) but no clear tendency was detected looking at increasing biochar amounts (Table 2).

\subsubsection{Plant Height}

Plant height increased on both substrate types with nearly all amendments resulting in heights between $31.0-119.0 \mathrm{~cm}$ on sandy substrate (control: $62.6 \pm 3.1 \mathrm{~cm}$ ) and between $50.0-122.0 \mathrm{~cm}$ on loamy substrate (control: $78.6 \pm 3.5 \mathrm{~cm}$; Figure 3). Raising the total amounts of compost significantly increased plant heights only on sandy substrate $(p<0.001)$, on loamy substrate the effect was only visible as a tendency ( $p=0.15$; Table 2$)$. Biochar showed only significantly negative effect on plant heights in one application amount on sandy substrate $\left(150 \mathrm{Mg} \mathrm{ha}^{-1} ; p=0.04\right)$, leading to the conclusion there was no trend or tendency of biochar influencing plant heights.

Figure 3. Plant height of oat (Avena sativa L.) in $\mathrm{cm}$ on sandy (top) and loamy substrate (bottom) depicted for five treatments $(\mathrm{CO}=$ pure compost, $\mathrm{BC}-03=$ compost with $3 \mathrm{~kg} \mathrm{Mg}^{-1} w / w$ biochar, $\mathrm{BC}-05=$ compost with $5 \mathrm{~kg} \mathrm{Mg}^{-1} w / w$ biochar, $\mathrm{BC}-10=$ compost with $10 \mathrm{~kg} \mathrm{Mg}^{-1} w / w$ biochar) in five application amounts $\left(10,50,100,150,250 \mathrm{Mg} \mathrm{ha}^{-1}\right)$ versus control $(\mathrm{CTRL}=$ no amendment $)(n=5)$.

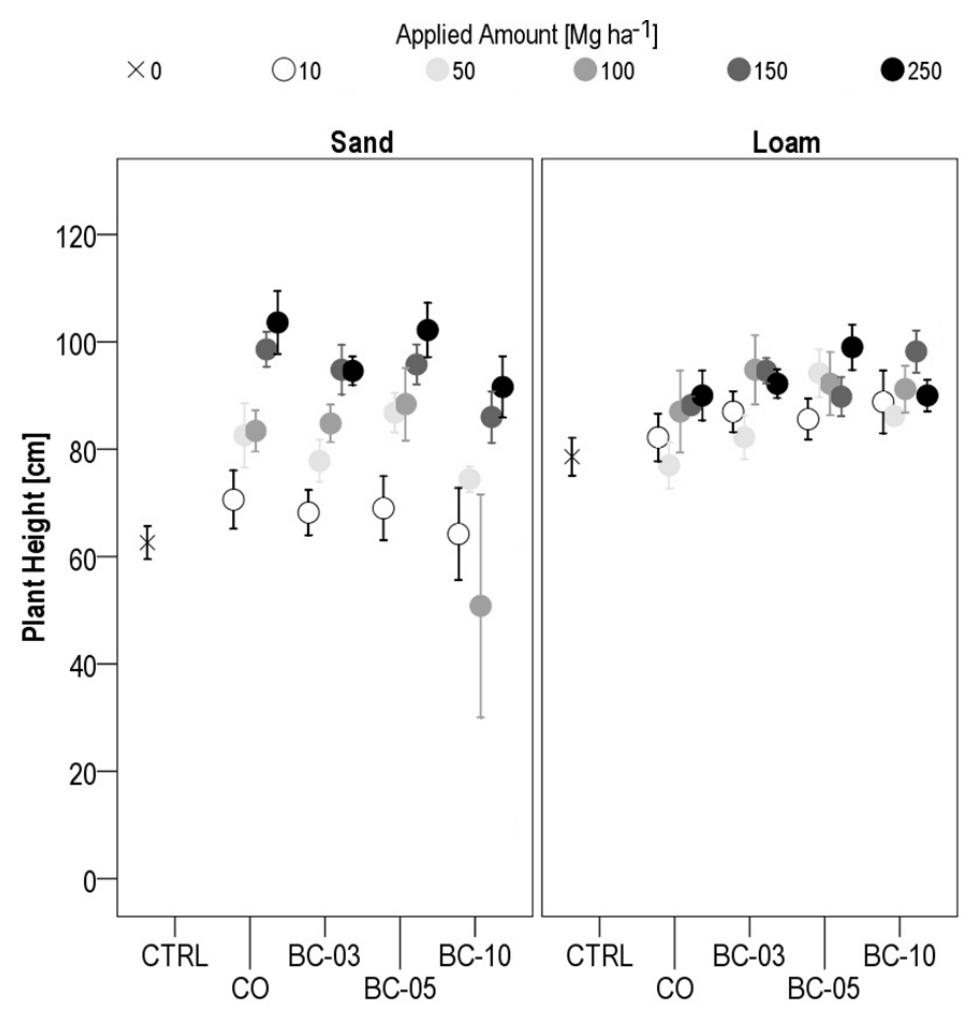




\subsection{Changes in Soil Properties}

\subsubsection{Total Organic Carbon (TOC)}

The TOC contents of sandy substrate ranged between 0.2 and $8.9 \mathrm{~g} \mathrm{~kg}^{-1}$ (control: $1.1 \pm 0.3 \mathrm{~g} \mathrm{~kg}^{-1}$ ) and between 4.0 and $31.1 \mathrm{~g} \mathrm{~kg}^{-1}$ on loamy substrate (control: $18.1 \pm 0.4 \mathrm{~g} \mathrm{~kg}^{-1}$; Figure 4). Compost amendments significantly increased TOC contents on both sandy and on loamy substrates $(p<0.001)$, while no significant biochar effect could be observed (Table 2).

\subsubsection{Total Nitrogen $\left(\mathrm{N}_{\text {tot }}\right)$}

$\mathrm{N}_{\text {tot }}$ ranged from $0.00-0.71 \mathrm{~g} \mathrm{~kg}^{-1}$ on sandy substrate (control: $0.0 \pm 0.0 \mathrm{~g} \mathrm{~kg}^{-1}$ ) and from $0.20-2.49 \mathrm{~g} \mathrm{~kg}^{-1}$ on loamy substrate (control: $1.52 \pm 0.27 \mathrm{~g} \mathrm{~kg}^{-1}$; Figure 5). Significant influence on $\mathrm{N}_{\text {tot }}$ content was proven for compost on sandy and loamy substrate equally $(p<0.001$; Table 2$)$. Differences between the compost and the respective biochar compost applications were marginal and not significant; hence the applied low amounts of biochar did not influence $\mathrm{N}_{\text {tot. }}$. (Figure 5).

Figure 4. Total organic carbon (TOC) in $\mathrm{g} \mathrm{kg}^{-1}$ on sandy (top) and loamy substrate (bottom) depicted for five treatments $(\mathrm{CO}=$ pure compost, $\mathrm{BC}-03=$ compost with $3 \mathrm{~kg} \mathrm{Mg}^{-1} w / w$ biochar, BC-05 = compost with $5 \mathrm{~kg} \mathrm{Mg}^{-1} w / w$ biochar, $\mathrm{BC}-10=$ compost with $10 \mathrm{~kg} \mathrm{Mg}^{-1} w / w$ biochar) in five application amounts $\left(10,50,100,150,250 \mathrm{Mg} \mathrm{ha}^{-1}\right)$ versus control (CTRL $=$ no amendment $)(n=5)$.

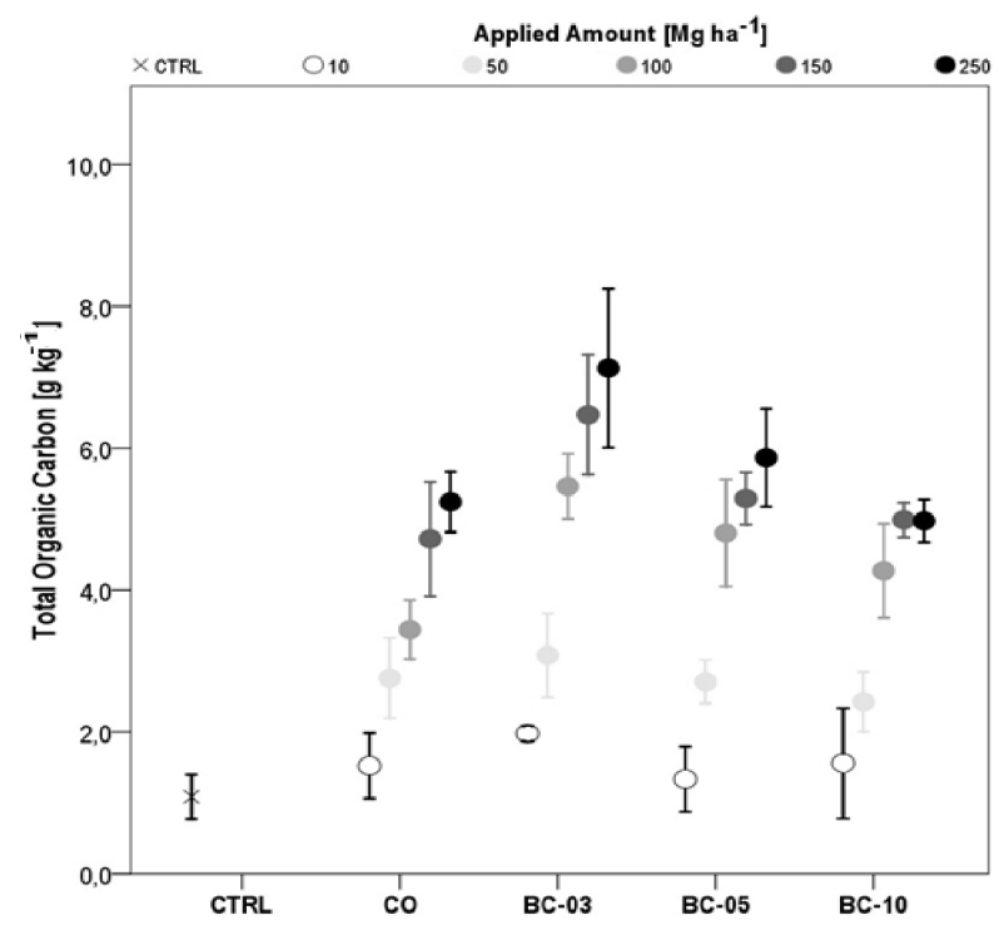


Figure 4. Cont.

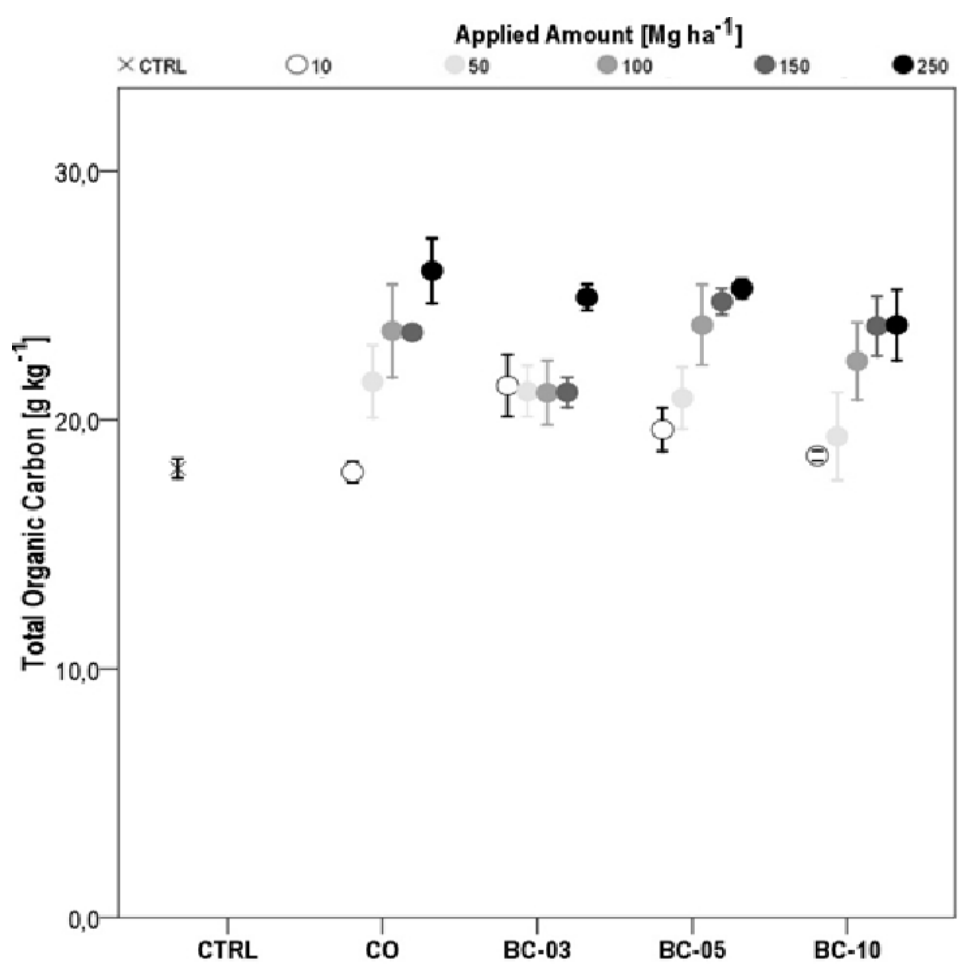

Figure 5. Total nitrogen $\left(\mathrm{N}_{\text {tot }}\right)$ in $\mathrm{g} \mathrm{kg}^{-1}$ on sandy (a) and loamy substrate (b) depicted for 5 treatments $\left(\mathrm{CO}=\right.$ pure compost, $\mathrm{BC}-03=$ compost with $3 \mathrm{~kg} \mathrm{Mg}^{-1} w / w$ biochar, BC-05 = compost with $5 \mathrm{~kg} \mathrm{Mg}^{-1} w / w$ biochar, $\mathrm{BC}-10=$ compost with $10 \mathrm{~kg} \mathrm{Mg}^{-1} w / w$ biochar) in five application amounts $\left(10,50,100,150,250 \mathrm{Mg} \mathrm{ha}^{-1}\right)$ versus control $(\mathrm{CTRL}=$ no amendment $)(n=5)$.

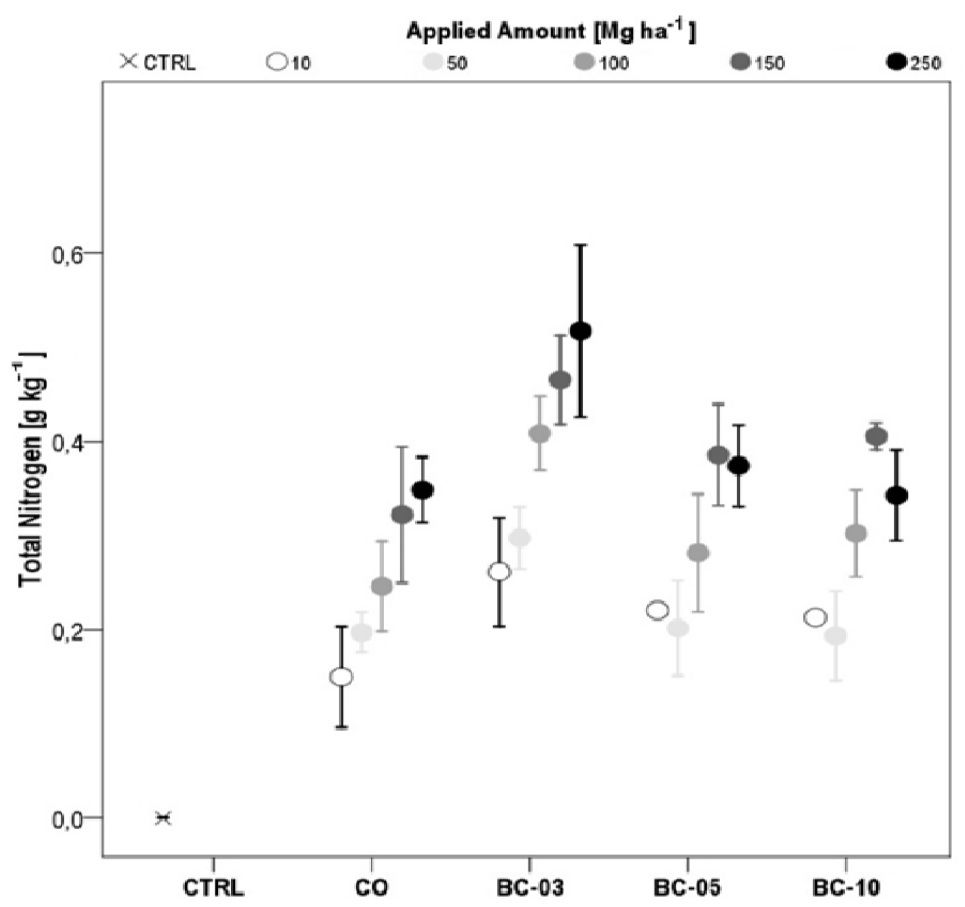




\subsubsection{Soil Reaction $(\mathrm{pH})$}

PH values ranged from 6.95-8.80 (sandy substrate control: $8.53 \pm 0.04$; mean: $8.33 \pm 0.03$ ) and 6.76-8.14 (loamy substrate control: $6.88 \pm 0.04$; mean: $7.31 \pm 0.02$ ). Alkalinity (rising $\mathrm{pH}$ ) was significantly influenced to a similar degree in both substrates by compost $(p<0.001)$.

\subsubsection{Plant-Available Nutrients and Aluminum}

Compost amendment enriched both substrate types significantly with phosphorus $(p<0.001$ on both substrates) boosting the phosphorus (P) content by factors of 2.3-30.1 compared to sandy control with factors of 1.2-3.4 compared to loamy control; however, there was no biochar effect. The contents of available potassium $(\mathrm{K})$ were elevated by factors of 1.4-3.0 on sand which was very significant in relation to compost additions; biochar amendments were proven to elevate $\mathrm{K}$ contents significantly at 50 and $250 \mathrm{Mg} \mathrm{ha}^{-1}$ application amounts while they showed a negative impact at $10 \mathrm{Mg} \mathrm{ha}^{-1}$ which brings us to the conclusion that there is no clear effect of biochar on $\mathrm{K}$ status in sandy substrate. Potassium load was increased only by factors 1.0-1.2 on loamy substrate, where compost contents significantly increased $\mathrm{K}$ at all application amounts and biochar amounts at $50 \mathrm{Mg} \mathrm{ha}^{-1}$ significantly decreased $\mathrm{K}$ with no other statistically significant influences in biochar. Plant-available calcium $(\mathrm{Ca})$, magnesium $(\mathrm{Mg})$ and sodium $(\mathrm{Na})$ contents were elevated with the highest statistical significance by the compost content of our amendments on both substrates $(p<0.001$, respectively); on sandy substrate biochar showed one exceptional significant response and elevated $\mathrm{Mg}$ contents at one particular application level (Figure 6, Table 2) while biochar increased $\mathrm{Ca}$ and decreased $\mathrm{Na}$ content significantly at one particular application level in each case on loamy substrate (Figure 7, Table 2). Contents of available Aluminum (Al) decreased the more compost was added to our two substrates $(p<0.001$ respectively); biochar did not show an effect that was statistically discernible on both substrates. Calcium content rose significantly after all applications especially on sandy substrate, leading to 17.7 times higher $\mathrm{Ca}$ contents at the highest application amounts, whereas on loamy substrate the factor was 2.1 at the same rate. This definitely had a positive influence on the Al-Ca-ratio, neutralizing the Aluminum. Ratios of Al to $\mathrm{Ca}$ were not critical to plant growth at any treatment level whatsoever. 
Figure 6. Plant-available nutrients and Aluminum (in cmolc $\mathrm{kg}^{-1}$ soil) on sandy substrate depicted for five treatments $\left(\mathrm{CO}=\right.$ pure compost, $\mathrm{BC}-03=$ compost with $3 \mathrm{~kg} \mathrm{Mg}^{-1} w / w$ biochar, $\mathrm{BC}-05=$ compost with $5 \mathrm{~kg} \mathrm{Mg}{ }^{-1} w / w$ biochar, $\mathrm{BC}-10=$ compost with $10 \mathrm{~kg} \mathrm{Mg}^{-1} w / w$ biochar) in five application amounts $\left(10,50,100,150,250 \mathrm{Mg} \mathrm{ha}^{-1}\right)$ versus control $(\mathrm{CTRL}=$ pure sandy substrate $)(n=5)$.

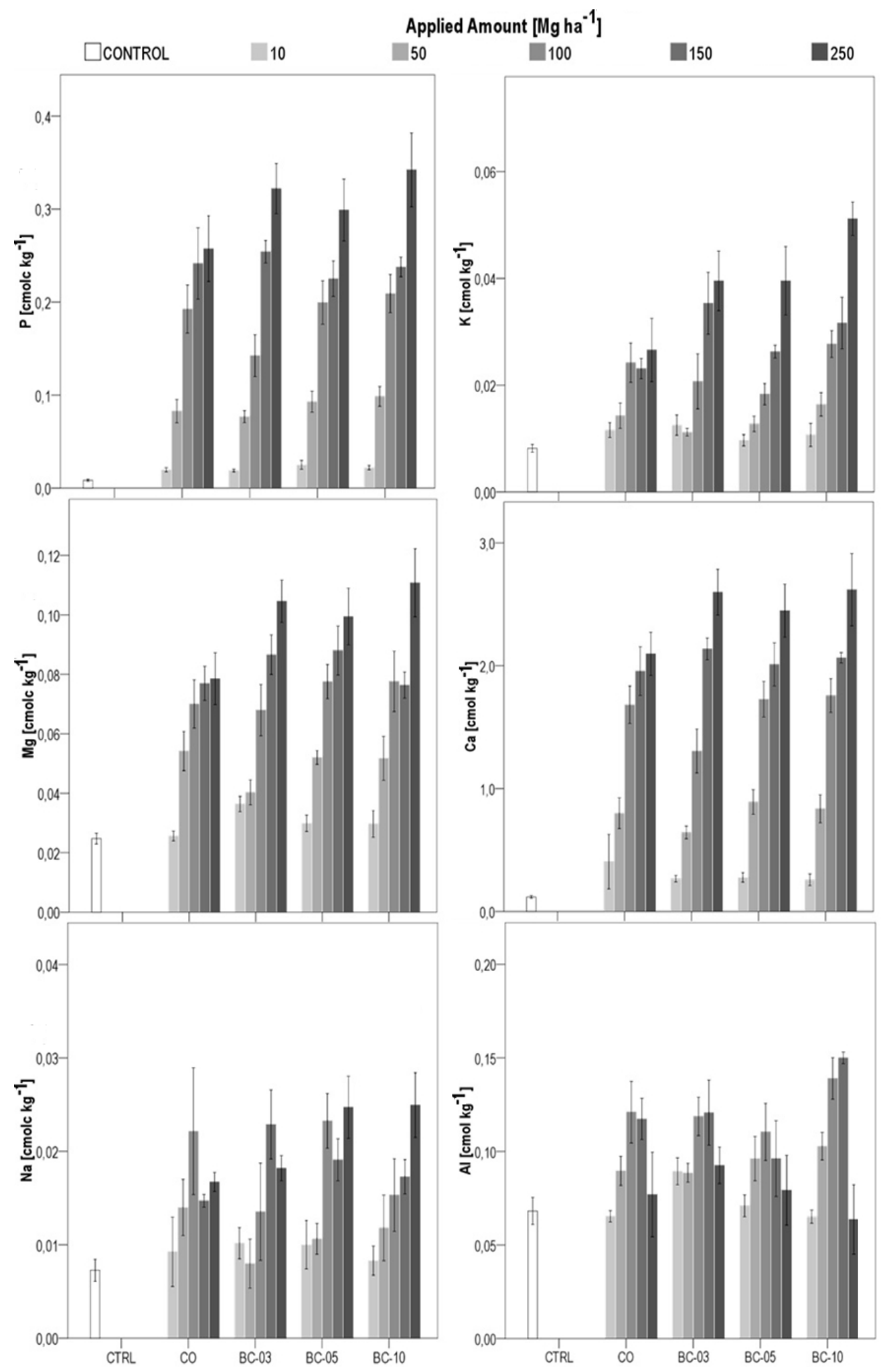


Figure 7. Plant-available nutrients and Aluminum (in cmolc $\mathrm{kg}^{-1}$ soil) on loamy substrate depicted for five treatments $\left(\mathrm{CO}=\right.$ pure compost, $\mathrm{BC}-03=$ compost with $3 \mathrm{~kg} \mathrm{Mg}^{-1} w / w$ biochar, $\mathrm{BC}-05=$ compost with $5 \mathrm{~kg} \mathrm{Mg}$-1 $w / w$ biochar, $\mathrm{BC}-10=$ compost with $10 \mathrm{~kg} \mathrm{Mg}^{-1} w / w$ biochar) in five application amounts $\left(10,50,100,150,250 \mathrm{Mg} \mathrm{ha}^{-1}\right)$ versus control $(\mathrm{CTRL}=$ pure loamy substrate $)(n=5)$.

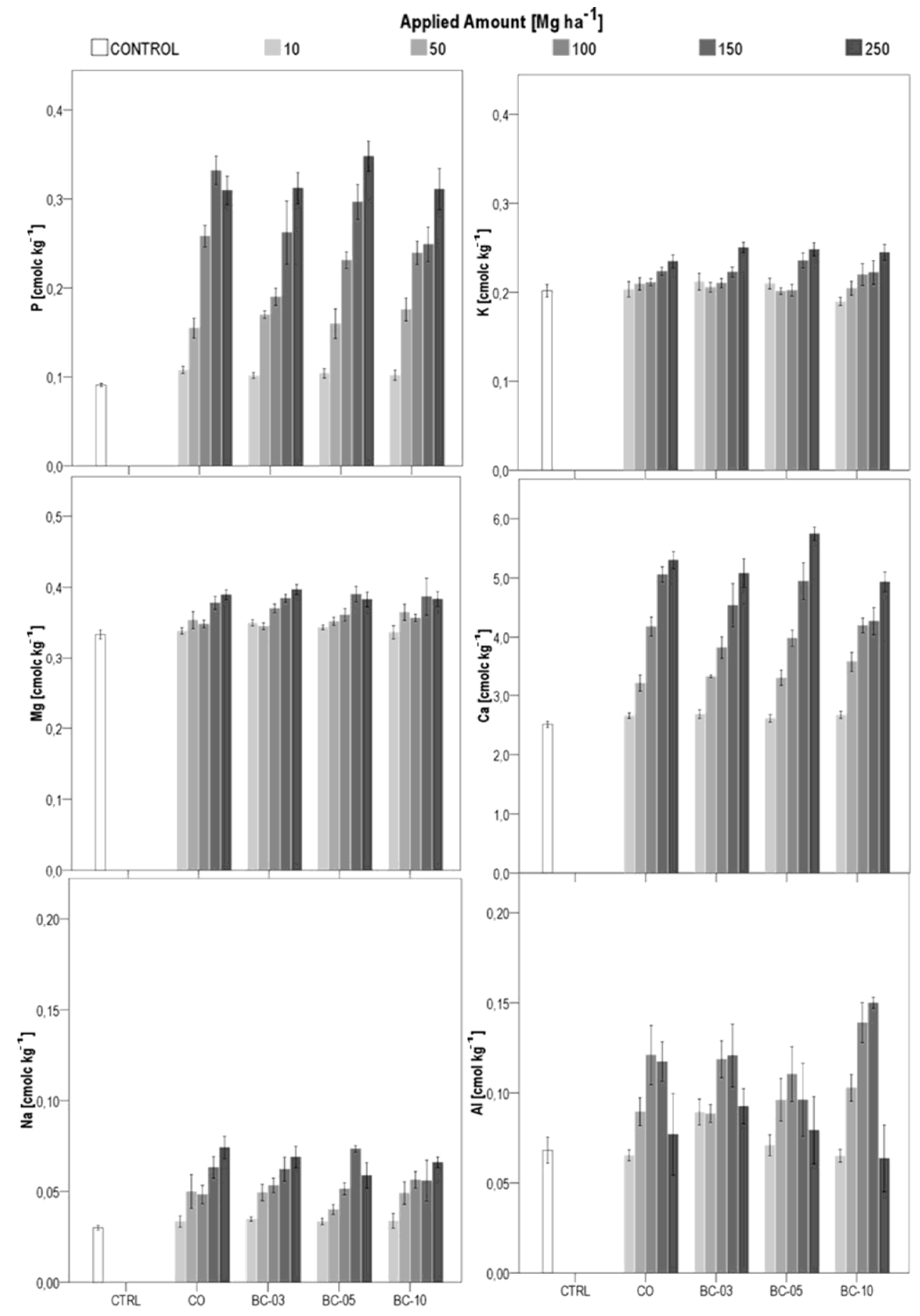




\section{Discussion}

Plant growth significantly increased with increasing compost amendment in both soil substrates (Figures 1-3). However, we could not prove any biochar effect on plant growth in our study which is in contrast to most other reported biochar research [2-4,7]. This is probably due to the extremely low amounts of biochar of $0.03-2.5 \mathrm{Mg} \mathrm{ha}^{-1}$ used in the different compost application amounts. The biochar effect is masked by compost. Additionally, a special type of biochar was used (activated carbon) which is known to be valuable for element sorption but perhaps this is not the case in a plant-available form. Another reason why we could not detect a significant influence by the biochar could be the limited duration of our trial. Several authors discussed reactions of biochar in soils over time increasing its impact through surface oxidation and bio-activation with soil microbes and fungi growing on the biochar [14-16].

Plant growth results of the different biochar composts showed increases in much larger magnitudes on sandy substrate than on loamy substrate, which was suggested by [17] who wrote that soil fertility of poorer soils would improve more in reaction to organic amendments. The different reactions of the two soil substrates could be also proven in a further greenhouse study by Schulz and Glaser [7] by using similar soil substrates and gaining similar results comparing the soil substrates' differing responses. In the study mentioned, we found the alterations of TOC, $\mathrm{N}_{\text {tot }}$, soil reaction and plant-available nutrients appearing in much bigger orders on sandy substrate following compost and composted biochar applications. This difference in the effects could be related to the low baseline of the pure sand regarding initial nutrient status, clay minerals and organic components. It could also be connected to the initially high soil reaction of the sandy substrate ( $\mathrm{pH}$ around 8 in sandy substrate, contrasting a $\mathrm{pH}$ around 7 in loamy substrate).

It is difficult to relate the results of our minimal biochar additions to the frequently published proofs that biochar applications to soil increase agricultural productivity (e.g. [1,3,4,18-20] due to the higher biochar application amounts used in these studies and because their biochar effects were not masked with the compost effects. Steiner et al. [21] reported cumulative yield increases of rice and sorghum on a Brazilian Amazon Oxisol of approximately 75\% after four growing seasons over two years, when $11 \mathrm{Mg} \mathrm{ha}^{-1}$ biochar was applied at the beginning of the experiment. In a degraded Kenyan Oxisol, Kimetu et al. [22] found a doubling of cumulative maize yield after three repeated biochar applications of $7 \mathrm{Mg} \mathrm{ha}^{-1}$ over two years corresponding to a total of $21 \mathrm{Mg} \mathrm{ha}^{-1}$.

If biochar was applied in higher amounts than in our study, soil nutrient availability has repeatedly been increased in highly weathered tropical soils comparable (Lehmann et al. [23] with $\sim 560 \mathrm{Mg} \mathrm{ha}^{-1}$; Lehmann et al. [18] with 67.6-135.2 $\mathrm{Mg} \mathrm{ha}^{-1}$; Steiner et al. [21] 2008 with $\left.11 \mathrm{Mg} \mathrm{ha}^{-1}\right)$. Similar amounts as in our study were tested in the trial from Iswaran et al. [24] where they showed increased biomass production in a poor sandy soil after adding small amounts of charcoal of $0.5 \mathrm{Mg} \mathrm{ha}^{-1}$ together with sufficient artificial fertilization. The positive effect of charcoal was attributed to its positive effect on Rhizobium abundance by poisoning Rhizobium antagonists with charcoal inherent phenolic substances. As we did not apply legumes and, furthermore, did not experience other negative effects of biochar induced poisoning of soil biota, we cannot relate the data from Iswaran et al. [24] to our results. 
In many studies, biochar incorporation has been shown to induce soil alkalization which can increase soil nitrification [18,25-30], moreover also the high sorption capacity caused by aromaticity of the biochar could have an influence on nutrient cycling[1] — none of these effects could be achieved by our small application amounts in relation to amounts of compost added and the initial alkaline substrates. Neither did the increased porosity (indicated by the BET surfaces of the co-composted biochars, Table 1) significantly influence the sorption capacity as suggested by the marginal and non-linear differences in our nutrient data.

The compost addition positively and significantly influenced plant growth and soil properties as expected after long-term experience in compost applications [30,31]. Compost improved oat yield significantly stronger on sandy substrate than on loamy substrate, which could be attributed to the very low content of nutrients and organic matter in the pure sandy substrate where any low amendment would alter the conditions for plant growth [7]. Nitrogen loads of our compost products were designed for optimum nitrogen supply from the first year on, because-unlike natural/agricultural conditions - we did not need to consider water protection guidelines (adding 100-2500 kg N ha ${ }^{-1}$ at one time, as we did, would be far above the European guidelines). The same total application amounts of composted biochars (BC-03, $-05,-10)$ and the pure composts (CO) improved the soils to a similar degree; there are no statistical differences regarding plant biomass or seed yield, nutrient loads, organic matter or soil reaction between the treatments containing biochar and those that lack of it. Clearly, we owe the effects our amendments had on all measured parameters to the compost shares of our amendments. We attribute this absent biochar effect to the low amounts of added biochar $\left(<3 \mathrm{Mg} \mathrm{ha}^{-1}\right)$. It can be stated that investments for biochar amendments below $€ 2,000$ per hectare are irrelevant for improving plant growth and soil quality at given actual costs for biochar of around $€ 300-800$ per Mg biochar. Farmers' costs could be lowered if the biochar is produced locally and from farmyard waste or in a projected future when biochar would be accounted for actual carbon offset. Around $€ 27.600$ per hectare would be necessary to invest for the biochar application amounts which showed the biggest effect on grain yield (Avena sativa L.) in the study from Schulz and Glaser [9]. There, the strongest effect on grain yield (Avena sativa L.) was measured after applications of composted biochar comprising of $92 \mathrm{Mg}$ biochar ha ${ }^{-1}$ and $107 \mathrm{Mg}$ compost ha ${ }^{-1}$ (leading to a $300 \%$ higher yield on sandy substrate compared to the pure compost) leaving us with impossible investments for farmers. The meta-analysis study of Jeffery et al. [4] marked the best results at application amounts of $100 \mathrm{Mg}$ biochar ha ${ }^{-1}$, which requires investments of money no farmer would spend easily. One feasible option might be the application of $1 \mathrm{Mg}$ every year until a certain stock is established, or as discussed in Blackwell et al. [12] in form of bandings and thereby closer to the plants growing space. Agronomic considerations including increased crop productivity, reduced fertilizer and pesticide use need to be made at the farm scale.

\section{Conclusions}

We proved that low level biochar applications had no immediate effects on plant growth and soil fertility both in sandy and loamy soils. Our data suggests that co-composted biochar application could only be a better way to enhance plant yields and soil parameters if applied in doses higher than 
2.5 $\mathrm{Mg} \mathrm{ha}^{-1}$ or applied differently, e.g. as suggested by Blackwell [32], or loaded with nutrients (biochar activation). We found no negative effects of the applied activated carbon.

Due to the proclaimed longevity of the biochar in soils, all commercial "Terra Preta" producers should be obliged to thoroughly test their products and to provide convincing results of the claimed benefits, e.g. by providing scientific results with proper experimental setup and statistical design.

\section{Acknowledgments}

The authors acknowledge the German Ministry for Education and Research (BMBF) for financial support within the coordinated project "Climate protection: $\mathrm{CO}_{2}$ sequestration by use of biomass in a PYREG reactor with steam engine" (01LY0809F). We are indebted to Jie Liu for the lab work, Daniel Fischer for compost analyses and to Ananda Erben and Georg Lemmer for help at the greenhouse.

\section{Conflicts of Interest}

The authors declare no conflict of interest.

\section{References}

1. Glaser, B.; Lehmann, J.; Zech, W. Ameliorating physical and chemical properties of highly weathered soils in the tropics with charcoal-A review. Biol. Fertil. Soils 2002, 35, 219-230.

2. Sohi, S.P.; Krull, E.; Lopez-Capel, E.; Bol, R. A review of biochar and its use and function in soil. Adv. Agron. 2010, 105, 47-82.

3. Waters, D.; Zwieten, L.; Singh, B.; Downie, A.; Cowie, A.; Lehmann, J. Biochar in Soil for Climate Change Mitigation and Adaptation. In Soil Health and Climate Change; Singh, B.P., Cowie, A.L., Chan, K.Y., Eds.; Springer: Berlin/Heidelberg, Germany, 2011; pp. 345-368.

4. Jeffery, S.; Verheijen, F.G.A.; van der Velde, M.; Bastos, A.C. A quantitative review of the effects of biochar application to soils on crop productivity using meta-analysis. Agric. Ecosyst. Environ. 2011, 144, 175-187.

5. Chan, K.Y.; Xu, Z. Biochar: Nutrient Properties and Their Enhancement. In Biochar for Environmental Management: Science and Technology; Lehmann, J., Joseph, S., Eds.; Earthscan: London, UK, 2009; pp. 67-84.

6. Singh, B.; Singh, B.P.; Cowie, A.L. Characterisation and evaluation of biochars for their application as a soil amendment. Soil Res. 2010, 48, 516-525.

7. Schulz, H.; Glaser, B. Effects of biochar compared to organic and inorganic fertilizers on soil quality and plant growth in a greenhouse experiment. J. Plant Nutr. Soil Sci. 2012, 175, 410-422.

8. Fischer, D.; Glaser, B. Synergisms between Compost and Biochar for Sustainable Soil Amelioration. In Management of Organic Waste; Kumar, S., Bharti, A., Eds.; Intech: Shanghai, China, 2012.

9. Schulz, H.; Dunst, G.; Glaser, B. Positive effects of composted biochar on plant growth and soil fertility. Agron. Sustain. Dev. 2013, 33, 817-827. 
10. Wiedner, K.; Baumgartl, M.-L.; Favilli, F.; Criscuoli, I.; Walther, S.; Fischer, D.; Miglietta, F.; Glaser, B. Surface Oxidation of Modern and Fossil Biochars. In Proceedings of the Eurosoil, Bari, Italy, 2-6 July 2012.

11. Wiedner, K.; Naisse, C.; Rumpel, C.; Pozzi, A.; Wieczorek, P.; Glaser, B. Chemical modification of biomass residues during hydrothermal carbonization-What makes the difference, temperature or feedstock? Org. Geochem. 2013, 54, 91-100.

12. Blackwell, P.; Krull, E.; Butler, G.; Herbert, A.; Solaiman, Z. Effect of banded biochar on dryland wheat production and fertiliser use in south-western Australia: An agronomic and economic perspective. Soil Res. 2010, 48, 531-545.

13. Mehlich, A. Mehlich 3 soil test extractant: A modification of Mehlich 2 extractant. Commun. Soil Sci. Plant Anal. 1984, 15, 1409-1416.

14. Ding, W.-C.; Zeng, X.-L.; Wang, Y.-F.; Du, Y.; Zhu, Q.-X. Characteristics and performances of biofilm carrier prepared from agro-based biochar. China Environ. Sci. 2011, 31, 451-1455.

15. Nguyen, B.T.; Lehmann, J.; Hockaday, W.C.; Joseph, S.; Masiello, C.A. Temperature sensitivity of black carbon decomposition and oxidation. Env. Sci. Tec. 2010, 44, 3324-3331.

16. Cheng, C.-H.; Lehmann, J.; Engelhard, M.H. Natural oxidation of black carbon in soils: Changes in molecular form and surface charge along a climosequence. Geochimica et Cosmochimica Acta 2005, 72, 1598-1610.

17. Glaser, B.; Birk, J.J. State of the scientific knowledge on properties and genesis of Anthropogenic Dark Earths in Central Amazonia (terra preta de Índio). Geochim. Cosmochim. Acta 2012, 82, $39-51$.

18. Lehmann, J.; Pereira da Silva, J.; Steiner, C.; Nehls, T.; Zech, W.; Glaser, B. Nutrient availability and leaching in an archaeological Anthrosol and a Ferralsol of the Central Amazon basin: Fertilizer, manure and charcoal amendments. Plant Soil 2003, 249, 343-357.

19. Marris, E. Putting the carbon back: Black is the new green. Nature 2006, 442, 624-626.

20. Blackwell, P.; Riethmuller, G.; Collins, M. Biochar Application to Soil. In Biochar for Environmental Management: Science and Technology; Lehmann, J., Joseph, S., Eds.; Earthscan: London, UK, 2009; 67-84.

21. Steiner, C.; Teixeira, W.; Lehmann, J.; Nehls, T.; de Macêdo, J.; Blum, W.; Zech, W. Long term effects of manure, charcoal and mineral fertilization on crop production and fertility on a highly weathered Central Amazonian upland soil. Plant Soil 2007, 291, 275-290.

22. Kimetu, J.M.; Lehmann, J.; Ngoze ,S.O.; Mugendi, D.N.; Kinyangi, J.M.; Riha, S.; Verchot, L.; Recha, J.W.; Pell, A.N. Reversibility of soil productivity decline with organic matter of differing quality along a degradation gradient. Ecosystems 2008, 11, 726-739.

23. Lehmann, J.; da Silva, J.P., Jr.; Rondon, M.; Cravo, M.S.; Greenwood, J.; Nehls, T.; Steiner, C. Slash-and-char-A Feasible Alternative for Soil Fertility Management in the Central Amazon. In Proceedings of the 17th World Congress of Soil Science, Bangkok, Thailand, 14-21 August 2002.

24. Iswaran, V.; Jauhri, K.S.; Sen, A. Effect of charcoal, coal and peat on the yield of moong, soybean and pea. Soil Biol. Biochem. 1980, 12, 191-192.

25. Yamato, M.; Okimori, Y.; Wibowo, I.; Anshori, S.; Ogawa, M. Effects of the application of charred bark of Acacia mangium on the yield of maize, cowpea and peanut, and soil chemical properties in South Sumatra, Indonesia. J. Soil Sci. Plant Nutr. 2006, 52, 489-495. 
26. DeLuca, T.H.; MacKenzie, M.D.; Gundale, M.J. Biochar Effects on Soil Nutrient Transformations. In Biochar for Environmental Management: Science and Technology; Lehmann, J., Joseph, S., Eds.; Earthscan: London, UK, 2009; pp. 251-270.

27. Topoliantz, S.; Ponge, J.; Ballof, S. Manioc peel and charcoal: A potential organic amendment for sustainable soil fertility in the tropics. Biol. Fertil. Soils 2005, 41, 15-21.

28. Oguntunde, P.G.; Fosu, M.; Ajayi, A.E.; Giesen, N. Effects of charcoal production on maize yield, chemical properties and texture of soil. Biol Fertil Soils 2004, 39, 295-299.

29. Hua, L.; Wu, W.X.; Liu, Y.X.; McBride, M.; Chen, Y.X. Reduction of nitrogen loss and $\mathrm{Cu}$ and Zn mobility during sludge composting with bamboo charcoal amendment. Environ. Sci. Pollut. R. 2009, 16, 1-9.

30. Amlinger, F.; Peyr, S.; Geszti, J.; Dreher, P.; Karlheinz, W.; Nortcliff, S. Beneficial Effects of Compost Application on Fertility and Productivity of Soils. In Federal Ministry for Agricultural and Forestry, Environment and Water Management; Lebensministerium: Vienna, Austria, 2007.

31. Diacono, M.; Montemurro, F. Long-term effects of organic amendments on soil fertility. J. Sustain. Agric. 2011, 2, 761-786.

32. Blackwell, P.; Shea, S.; Storer, P.; Solaiman, Z.; Kerkmans, M.; Stanley, I. Improving Wheat Production with Deep Banded Oil Mallee Charcoal in Western Australia. In Proceedings of the First Asia Pacific Biochar Conference, Terrigal, Australia, 29 April-2 May 2007.

(C) 2014 by the authors; licensee MDPI, Basel, Switzerland. This article is an open access article distributed under the terms and conditions of the Creative Commons Attribution license (http://creativecommons.org/licenses/by/3.0/). 